\title{
FACTORS INFLUENCING THE PERCEPTION OF DRINKING WATER
}

\section{FAKTORI KOJI UTIČU NA PERCEPCIJU VODE ZA PIĆE}

Nikolina Banjanin 1

\section{Summary}

Drinking water represents one of the basic needs of the human body, and it is necessary for its normal functioning. Many factors have impact on perception of drinking water quality and safety. But, opinions about their individual importance are conflicting.

Level of customers' education has impact on perception of drinking water safety. Fear of potential health risk and consumers' origin affect the selection of the type of drinking water. Certainly, demographic characteristics such as gender and age are important. Very significant role in the perception of drinking water quality and safety have its organoleptic properties. The presence of chemicals in drinking water and information obtained by family and friends are also important. On perception of drinking water properties nutritional status and the level of family income have significant impact.

Scientific investigations and their results have outstanding significance in determination of standards of safety and quality of drinking water. But, opinions and attitudes of consumers should be taken into account, as well as factors they consider and observe as important.

Keywords: drinking water, organoleptic properties, safety, demographic characteristics

\section{Sažetak}

Voda za piće predstavlja jednu od osnovnih potreba ljudskog organizma i neophodna je za njegovo normalno funkcionisanje. Na percepciju kvaliteta i bezbednosti vode za piće utiču mnogobrojni faktori. Međutim, mišljenja su oprečna kada je u pitanju njihov pojedinačni značaj.

Stepen obrazovanja potrošača ima uticaj na percepciju bezbednosti vode za piće. Na odabir vrste vode za piće utiče i strah od potencijalnog zdravstvenog rizika, kao i poreklo potrošača. Svakako su važne i demografske karakteristike kao što su uzrast i pol. Izuzetno značajnu ulogu u percepciji kvaliteta i bezbednosti vode za piće zauzimaju njena organoleptička svojstva. Prisustvo hemikalija u vodi za piće i informacije dobijene od porodice i prijatelja takođe su bitne. Na percepciju osobina vode za piće značajno utiču i stepen uhranjenosti ispitanika i nivo primanja u porodici.

Naučna istraživanja i njihovi rezultati imaju izuzetan značaj u određivanju standarda bezbednosti i kvaliteta vode za piće. Međutim, važno je sagledati i mišljenja i stavove potrošača, kao i faktore koje oni smatraju i opažaju bitnim.

Ključne reči: voda za piće, organoleptička svojstva, bezbednost, demografske karakteristike

\section{UvoD}

Voda za piće predstavlja jednu od osnovnih potreba ljudskog organizma i neophodna je za njegovo normalno funkcionisanje. Prema zakonu o bezbednosti hrane voda za piće je voda u originalnoj ambalaži i voda za javno snabdevanje stanovništva (1). Prema pravilniku o higijenskoj ispravnosti vode za piće higijenski ispravnu vodu za piće predstavlja voda koja odgovara u pogledu: mikrobioloških osobina, prisustva hemijskih supstancija, ostataka koagulacionih i flokulacionih sredstava, ostataka dezinfekcionih sredstava i sporednih proizvoda dezinfekcije, fizičkih, fizičko-hemijskih i hemijskih osobina i radioloških osobina (2). Svetska zdravstvena organizacija uvek daje prednost mikrobiološkoj ispravnosti vode i smatra da efikasna dezinfekcija nikada ne sme da bude kompromitovana (3). Na percepciju kvaliteta i bezbednosti vode za piće utiču mnogobrojni faktori. Međutim, mišljenja su oprečna kada je u pitanju pojedinačni značaj tih faktora. Takođe, među potrošačima postoji neujednačen stav da li treba koristiti flaširanu vodu ili vodovodsku vodu za piće. Prema Pravilniku o higijenskoj ispravnosti vode za piće flaširana prirodna voda za piće jeste voda izvanrednih prirodnih fizičko-hemijskih, mikrobioloških i radioloških osobina, koja se iz higijenski kaptiranog izvora obezbeđenog sanitarno-zaštitnim zonama, neposredno na izvoru puni u sterilnu ambalažu bez prethodnog prečišćavanja i dezinfekcije, izuzev dezinfekcije radijacijama (2). Svetska zdravstvena organizacija navodi da je upotreba flaširane vode u porastu u mnogim zemljama. Takođe, smatra da je snabdevanje flaširanom vodom odgovarajuće u izvesnim situacijama kao što je ozbiljna kontaminacija sistema za snabdevanje vodom za piće kao i snadbevanje flaširanom vodom domaćinstava sa malom decom ukoliko su vodovodi kontaminirani visokim nivoom nitrata u cilju sprečavanja methemoglobinemije (4). Rezultati studija koje su ispitivale značaj pojedinih faktora u percepciji bezbednosti i kvaliteta i bezbednosti vode za piće su heterogeni verovatno zbog njihovih različitih dizajna kao i mnogih drugih faktora.

\section{STAVOVI I MIŠLJENJA POTROŠAČA O VODI ZA PIĆE}

Stepen obrazovanja potrošača ima uticaj na percepciju bezbednosti vode za piće. Studija u Kaliforniji pokaza- 
la je da $68 \%$ odraslih ispitanika prvenstveno pije vodovodsku vodu i da $29 \%$ ispitanika smatra da je flaširana voda bezbednija od vodovodske. Pri tome, obrazovaniji su manje od niže obrazovanih mišljenja da je flaširana voda bezbednija (5). Percepcija bezbednosti vode za piće je od izuzetnog značaja za potrošače. Tako, u Sjedinjenim Američkim Državama ispitanici koji nemaju poverenje u bezbednost vode za piće kod kuće 4,8 puta više kao primarni izvor vode za piće biraju flaširanu vodu (6). $\mathrm{Na}$ odabir vrste vode za piće utiče i strah od potencijalnog zdravstvenog rizika, kao i poreklo potrošača. Naime, pokazano je da roditelji Latinoamerikanci ređe piju vodovodsku vodu i ređe je daju svojoj deci u odnosu na roditelje koji nisu Latinoamerikanci jer imaju strah od bolesti (7). U različitim zemljama i geografskim područjima potrošači imaju različitu dostupnost vodovodske vode. Prema rezultatima studije u jugozapadnoj Etiopiji samo $18,1 \%$ ispitanika koristi vodovodsku vodu (8).

Između ostalih demografskih karakteristika uzrast i pol imaju značajno mesto. Naime, prema istraživanju upotreba vodovodske vode bila je češća kod dece školskog uzrasta nego kod dece uzrasta od 1 do 2 godine. Takođe, kada je reč o polu, pokazano je da devojke ređe koriste vodovodsku vodu (9). Izuzetno značajno mesto u percepciji kvaliteta i bezbednosti vode za piće zauzimaju njena organoleptička svojstva. Bitnu ulogu igra i pritisak vodovodske vode.

Rezultati istraživanja u Alabami ukazuju da je $20 \%$ ispitanika prijavilo da postoji problem sa ukusom, mirisom i bojom vode, pri čemu je najviše primedbi bilo na njen ukus. Nizak pritisak vode iskusilo je 35,3\% ispitanika (10). U studiji sprovedenoj u Portugaliji i Ujedinjenom Kraljevstvu pritiskom vode zadovoljniji su bili ispitanici u Portugaliji u odnosu na ispitanike u Ujedinjenom Kraljevstvu (11). Takođe, i ispitanici u Šangaju najviše su bili nezadovoljni ukusom vodovodske vode- $26,5 \%$ ispitani$\mathrm{ka}$, potom mirisom 9,5\% i bojom 7,5\% ispitanika (12). Veliki značaj ukusu kao organoleptičkom svojstvu dali su $\mathrm{i}$ ispitanici prosečnog uzrasta 19 godina u Masačusetsu i Luizijani, navodeći da im je najvažniji faktor pri odabiru napitaka upravo ukus (13). U Južnoj Africi na opažanje vode kao bezbedne više utiču njen ukus i miris nego socio-ekonomske i demografske karakteristike (14).
Studija sprovedena u Ujedinjenom Kraljevstvu i Portugaliji pokazala je da ispitanici obe zemlje smatraju da je vodovodska voda dobrog kvaliteta. Međutim, postoji diskrepanca u mišljenjima kada su u pitanju pojedine osobine vode. Naime, zadovoljstvo bojom vode bilo je veće je u Ujedinjenom Kraljevstvu, i stanovnike Ujedinjenog Kraljevstva mnogo više brinu hemikalije o kojima su i informisaniji. Takođe, negativne informacije dobijene od porodice i prijatelja učestalije su u Ujedinjenom Kraljevstvu nego u Portugaliji (11). Iz navedenog se može zaključiti da značajno mesto u percepciji kvaliteta vode za piće zauzimaju i prisustvo hemikalija u vodi za piće kao i infomacije dobijene od porodice i prijatelja. Takođe, na percepciju bezbednosti vode za piće utiču i stepen uhranjenosti i nivo primanja u porodici. Naime, mladi koji su gojazni i koji su iz porodica sa nižim primanjima češće su mišljenja da je vodovodska voda nebezbedna. U 56, 7 \% opažanje bezbednosti vodovodske vode bilo je u saglasnosti sa opažanjima roditelja (15).

\section{ZAKLJUČAK}

Na percepciju bezbednosti i kvaliteta vode za piće utiču mnogobrojni faktori kao što su stepen obrazovanja potrošača, strah od potencijalnog zdravstvenog rizika, poreklo potrošača, različita geografska područja, uzrast, pol, organoleptička svojstva vode za piće, pritisak vodovodske vode, informacije dobijene od porodice $\mathrm{i}$ prijatelja. Naučna istraživanja obezbeđuju validne podatke i njihovi rezultati imaju izuzetan značaj u određivanju standarda bezbednosti i kvaliteta vode za piće. Međutim, važno je sagledati i želje, mišljenja i stavove potrošača, kao i faktore koje oni smatraju i opažaju bitnim. Poverenje potrošača je svakako bitno, te ih kontinuirano treba edukovati o faktorima koji određuju bezbednost i kvalitet vode za piće.

\section{ZAHVALNICA}

Autor se zahvaljuje Doc. dr Katarini Paunović na inspiraciji i podršci u pisanju ovog rada.

6. Hu Z, Morton LW, Mahler RL. Bottled water: United States consumers and their perceptions of water quality. Int J Environ Res Public Health 2011; 8(2): 565-78.

7. Hobson WL, Knochel ML, Byington CL, Young PC, Hoff CJ, Buchi KF. Bottled, filtered, and tap water use in Latino and non-Latino children. Arch Pediatr Adolesc Med 2007; 161 (5): 457-61.

8. Yasin M, Ketema T, Bacha K. Physico-chemical and bacteriological quality of drinking water of different sources, Jimma Zone, Southwest Ethiopia. BMC Res Notes 2015; 8 (1):541.

9. Patel AI, Shapiro DJ, Wang YC, Cabana MD. Sociodemographic characteristics and beverage intake of children who drink tap water. Am J Prev Med 2013; 45 (1):75-82. 
10. Wedgworth JC, Brown J, Johnson P, Olson JB, Elliott M, Forehand R, Stauber CE. Associations between perceptions of drinking water service and measured drinking water quality in rural Alabama. Int J Environ Res Public Health 2014; 11 (7):7376-92.

11. Doria Mde F, Pidgeon N, Hunter PR. Perceptions of drinking water quality and risk and its effect on behaviour: a cross-national study. Sci Total Environ 2009; 407(21): 5455-64.

12. Chen H, Zhang Y, Ma L, Liu F, Zheng W, Shen Q, Zhang H, Wei X, Tian $\mathrm{D}, \mathrm{He} \mathrm{G}, \mathrm{Qu}$ W. Change of water consumption and its potential influential factors in Shangai: a cross-sectional study. BMC Public Health 2012; 12:450

13. Block JP, Gillman MW, Linakis SK, Goldman RE. „If it tastes good, I' $m$ drinking it ,: qualitative study of beverage consumption among college students. J Adolesc Health 2013; 52 (6): 702-6.

14. Wright JA, Yang H, Rivett U, Gundry SW. Public perception of drinking water safety in South Africa 2002-2009: a repeated cross-sectional study. BMC Public Health 2012; 12:556.

15. Onufrak SJ, Park S, Sharkey JR, Merlo C, Dean WR, Sherry B. Perceptions of tap water and school water fountains and association with intake of plain water and sugar-sweetened beverages. J Sch Health 2014; 84 (3): 195-204. 